\title{
An Analysis of Impact of Demonetization on Black Money in India
}

\author{
Dr. Neeraj Emmanuel Eusebius \\ Assistant Professor Department Of Economics, St. John's College, Agra
}

\begin{abstract}
India being the largest democracy in the world with a population of over 1.25 crores have to cater to the need of a greatly diverse society. Since Independence measures have been taken by different governments in order to achieve high rate of economic growth. The efforts taken in this direction have been subdued by the rising population accompanied by corruption in the society. The BJP Government led by the Prime Minister Mr. Narendra Modi took a massive step which was to Demonetize the two major currency notes of rupees 500 and rupees 1000 in order to curb the menace of black money prevalent in the society. This paper aims to analyse the positive and the negative impacts of the entire demonetization process. In order to study the impact of the process this paper laid a great emphasis on differentiating between Undisclosed income and Black and also tried to answer a critical question of whether the black money was discovered or destroyed in the entire process. It was observed that the process has effected differently to the different sections of the society and has not been able to achieve the tall claims as have been suggested by the government. However this has certainly created awareness and a caution regarding the accumulation of black money in India.
\end{abstract}

\section{Introduction}

The people of the country had just enjoyed the festival of light which is Diwali and had worshipped the Goddess of Wealth Laxmi and they had no clue what is in store for them a few days later . On November 8 , the Prime Minister of the country Mr Narendra Modi announced that post mid night the most circulated currencies in the denomination of Rs,500 and Rs. 1000 will be considered as illegal tender. The reason given to the citizens was that the measure will serve as a tonic for curbing the menace of black money in the country. It was also stated that a large amount of fake currency which is in circulation is in the form of 500 and 1000 currency notes and making these currency illegal tender will also affect their circulation making them obsolete and along with this a major problem of terrorism which the country is facing in the form of Inter Services Intelligence of Pakistan and the naxalities movement will also be effected due to the demonetization of the major currencies. The measure invoked a mix response from the citizens of the country. Some treated it as a revolution in the functioning of the country, some considered it as the dawn of the new era and some regarded it as a dangerous step which will destroy the economy of the country. Some remedial measures were also initiated by the government in order to make it convenient for the people to utilized the amount of currency they have in 500 and 1000 rupee denomination. The Government fixed $31^{\text {st }}$ December, 2016 as the deadline for depositing the cash at the banks and alongwith this the government also announced that the old currency notes will be accepted for emergency services such as the hospitals, petrol pumps and railway reservation. The Government also announced some measures to reduce the agony of the people from time to time till the $31^{\text {st }}$ of December, 2016 . The Foreign citizens were permitted to exchange foreign currency up to Rs. 5000 per week. Necessary entry to this effect was made in their passports. Separate queues were arranged for Senior Citizens and Divyang persons, customers with accounts in the Bank and for customers for exchange of notes. The weekly limit of Rs 20,000 for withdrawal from Bank accounts was increased to Rs 24,000. The limit of Rs 10,000 per day was removed. Business entities having Current Accounts which were operational for last three months or more were allowed to draw Rs 50,000 per week. ATM Withdrawal limit increased to Rs 2,500 per day for ATMs that were recalibrated. Farmers were permitted to withdraw up to Rs 25,000 per week in cash from their KYC compliant accounts only. Families celebrating weddings were permitted to draw up to Rs 2,50,000 in cash from their own KYC compliant bank accounts. All Central Government Departments and Public Sector Enterprises were instructed to use the method of e-payments to the maximum extent possible.

\section{Review Of Literature}

Tandon and Kulkarni (2017) analyzed that there is no guarantee that in future, no black money will be generated. The queues of the people before the banks are said to be flooded by the workers of the political party leaders to deposit the money in their accounts. In just 3 days Rs. 170 crore were deposited in the Jandhan Accounts opened with zero balances. 
EXPRESS WEB DESK (2016, Nov 19). Reported the news of the Sydney Morning Herald which stated that the step by Modi, who is approaching the half-way mark of his term, is an attempt to fulfil his election promise of curbing tax evasion and recovering illegal income, locally known as black money, stashed overseas. Modi's unprecedented move follows a similar step taken by the European Central Bank, which is discontinuing the use of 500-euro notes to stop their use in "illicit activities".

ECONOMICS CLUB OF IMI (2016, Nov 13) analyzed that this move is a vital step to curb the circulation of black money and counterfeit notes in the economy. However, India still has a long way to go in providing a digital infrastructure which in turn would provide a framework to keep track of the undisclosed income. There is also a risk of the two-thousand rupee note again starting the vicious circle of black money at a much higher rate this time.

PATNAIK, PRABHAT (2016, Nov 19) summarized that the decision to demonetize Rs 500 and Rs 1000 notes is misconceived and will not address the problem of black money

ZONG, RAYMOND AND SINGH, KARANDEEP (2016, Nov 18) observed that As authorities struggle to replace the more than 20 billion notes that are being yanked out of the economy to punish cash-hoarding tax evaders, the sudden scarcity of paper money is being felt most acutely far from India's megacities.

\section{Results And Discussion}

THE ECONOMICS OF BLACK MONEY BEING DISCOVERED OR DESTROYED: India being a developing economy has a task on hand. Black money provides a big bottleneck in its development but a question has to be asked as to whether the black money should be destroyed or discovered. In the present process of demonetization the black money was destroyed . It can be understood with an example. Suppose Mr. $\mathrm{X}$ is having Rs. 10000 as undisclosed income in the form of Rs.500 and Rs.1000 currency notes. Now he has three options to get rid of that currency.

OPTION 1 : To deposit the money in Bank

RESULT OF OPTION 1 : The money gets deposited in bank. The government can charge income tax on that money in future which may be $10 \%$ or more . Mr.X gets the benefit that $90 \%$ of his money is now white money but the problem is that Rs. 10000 which the government received is the illegal tender money and it cannot be used in the economy and eventually it has to be destroyed and replaced with the new currency. Now the economic burden upon the government is to bear the cost of printing 10000 worth new currency and for that it is only getting the $10 \%$ money in the form of Income Tax from Mr.X. So its a massive expenditure upon the government and minimum benefit for the economy.

OPTION 2 : To destroy the money

If Mr.X prefers to destroy Rs.10000 himself even then the money is lost and cannot be used for the benefit of the economy.

OPTION 3 : Try to adjust the money through illegal means

If Mr. X prefers to use unfair means like purchase train ticket worth Rs. 10000 and cancel it afterwards as the railways accepted the illegal tender money even after demonetization as per the instructions of the government even then the money which the government is getting from the purchase of tickets have to be eventually destroyed and it cannot be used for the benefit of the economy .

If the measures were such that the black money could have been discovered like through legal measures or income tax raids instead of demonetization then this Rs. 10000 being a legal tender money could have been used for the benefit of the economy and it could have been said that the Black money has been discovered.

FORWARD AND BACKWARD EFFECT OF DEMONETIZATION PROCESS.

Forward and Backward effects are two important ingredients of any policy to curb the flow of Black Money. The entire demonetization process only provided a backward effect by destroying the black money already accumulated in the country. It affected only the hard cash that was accumulated in the currency denomination of Rs.500 and Rs.1000. It never defined a process to stop the creation of black money in the economy.

\section{STATUS OF CURRENCY DEPOSITED DURING DEMONETIZATION}

According to a report of IYER VAIDYANATHAN P (2017) published in the Indian Express on January 10, 2017 Rs. 14 lacs crores of old currency notes were back with the government and only 75000 crores were out. "The approximate cost of printing each note of new Rs 500 currency note is in the range of Rs 2.87 to Rs 3.09 and for a Rs 2,000 note is Rs 3.54 to Rs 3.77," Minister of State for Finance Arjun Ram Meghwal said in a written reply in the Rajya Sabha. Hence in order to provide a replacement for about 14 lacs crores of old currency the government has to incur approx 21 lacs crores of rupees in order to provide the Indian Economy with the same amount of currency . Even after spending so much money and causing a panic in the country the ultimate gain of the demonetisation process is just a back ward effect that is it has no restriction on the fresh accumulation of black money in the country. 


\section{STATUS OF CASHLESS MODE AS SUGGESTED BY THE GOVERNMENT}

In order deal with the shortage of cash in the economy and to prevent the accumulation of Black Money in future the government went forward to convert the economy from cash economy to cashless economy promoting digital payments. According to KHOSLAN SAKSHAM (2016) the cashless india project is far far away from the target. Just as building more schools does not improve literacy rates, opening accounts does not empower citizens to make digital financial transactions. Key demand and supply-side gaps remain: $23 \%$ of PMJDY accounts lie empty. A recent investigation from September found that 10 million accounts held only Re. 1, as bank officials took matters into their own hands to reduce their branch's share of zero-balance accounts. A survey of PMJDY customers conducted by a financial inclusion consultancy found that only $33 \%$ of all beneficiaries were ready to use their Rupay cards. The others were bewildered by the complicated PIN and activation procedures. Inconsistent electricity and sporadic internet access further eroded customers' trust in ATMs and POS machines, with one failed transaction enough to make an entire village swear off formal financial institutions. This is as much a structural constraint as it is logistical. Card acceptance infrastructure struggles to keep pace with India's growing population: in 2014, there were 18 ATMs and 13 commercial bank branches per 100,000 adults - in comparison, the number in Brazil was 129 and 47 respectively. Between 2013 and 2015, debit cards grew twice as fast as the number of POS machines and one-and-a-half times the number of ATMs, with the majority of new infrastructure taking root in urban centres. India's modern banking system maps neatly onto social and spatial inequalities. Only $18 \%$ of all ATMs are deployed in rural India. The RBI's own research finds that states with a higher female population and a more rural populace show lower levels of financial inclusion.

The impact of mobile wallets in hastening the transition to a cashless economy is overstated. Merely $26 \%$ of India has internet access, and there are only 200 million users of digital payment services. The World Bank's Global Findex shows that Indians are significantly less familiar with digital banking - the use of credit or debit cards, making transactions using mobile phones, and using the internet to pay bills - than their peers in middleincome nations.

\section{Conclusions}

The major outcome of the entire demonetization process has been that it has created a sense of awareness amongst the people regarding black money and have also created a sense of fear in keeping with them money in the form of hard cash . In urban areas steps are still on to create awareness regarding cashless modes of payments but in the rural areas people are still reluctant to go cashless. As far as effecting black money is concerned this process has certainly destroyed the black money accumulated by the people but not to the much benefit of the economy as the money was not discovered but destroyed. What the future of black money in the country will still depend upon the legal and legislative measures to be taken by the government from time to time.

\section{References}

[1]. Tandon And Kulkarni (2017) Demonetization In India : Good, Bad And Ugly Facets , Asian Journal Of Research In Business Economics And Management Vol. 7, No. 1, January 2017, Pp. 41-47

[2]. Express Web Desk (2016, Nov 19). What Foreign Media Thinks About Pm Narendra Modi's Demonetization Move? Retrieved From:/Http://Indianexpress.Com/Article/India/India-News-India/What-Foreign-Media-Thinks-About-Pm-Narendra-ModisDemonetisation-Move-4383852

[3]. Economics Club Of Imi (2016, Nov 13). Economic Impact Of Demonetizing The Indian Rupee. Retrieved From: Https:// Economicsclubimi.Wordpress.Com/2016/11/13/ Economic-Impact-Of-Demonetizing-The-Indian-Rupee/

[4]. Nathan, Narendra (2016, Nov 14). How Demonetization And Donald Trump's Victory Impact Your Investments. Retrieved Http:// Economictimes.Indiatimes.Com /Articleshow/55384579.

[5]. Patnaik, Prabhat (2016, Nov 19). "Black Money" And India's Demonetization Project. Retrieved From: Http://Www. Globalresearch.Ca/Black-Money-And-Indias-Demonetization-Project/5557384

[6]. Zong, Raymond And Singh, Karandeep (2016, Nov 18). Barter Economy Is Reborn In Villages As India Cancels Cash. Retrieved From:Http://Blogs.Wsj.Com/Indiarealtime/2016/11/18/Barter-Economy-Is-Reborn-In-Villages-As-India-Cancels-Cash/

[7]. Iyer Vaidyanathan P (2017) Demonetization : Rs. 14 Lacs Crores In Old Notes Are Back, Only 75000 Crores Out. Retrieved From Http://Indianexpress.Com / Article / Business / Economy /Demonetisation-Black-Money-Cash-Crunch-Rs-14-Lakh-Crore-InOld-Notes-Are-Back-Only-Rs-75000-Crore-Out-Rbi4465542/

[8]. Khoslan Saksham(2016) India Is Far Away From Being A Cashless Economy Retrieved From Http://Www.Hindustantimes.Com/Analysis/India-Is-Far-Away-From-Being-A-Cashless-Economy-Here-S-Why/StoryYbfui5m53jpfyd1mgvhigj.Html 